Int. J. Environ. Res. Public Health 2008, 5(3) 147-151

International Journal of

Environmental Research and Public Health

ISSN 1661-7827

www.ijerph.org

(C) 2008 by MDPI

\title{
Effect of Garlic (Allium sativum) on Heavy Metal (Nickel II and ChromiumVI) Induced Alteration of Serum Lipid Profile in Male Albino Rats
}

\author{
Amrita Das Gupta ${ }^{1}$, Swastika N. Das ${ }^{2}$, Salim A. Dhundasi ${ }^{1}$ and Kusal K. Das ${ }^{1 *}$ \\ ${ }^{1}$ Environmental Health Research Unit, Department of Physiology, Al Ameen Medical College, Bijapur 586108 Karnataka, India \\ ${ }^{2}$ Department of Engineering Chemistry, B.L.D.E.A’s. Dr. P. G. Halakatti College of Engineering and Technology \\ *Correspondence to Dr. Kusal K. Das. E-mail: kusaldas@yahoo.com
}

Received: 12 February 2008 / Accepted: 15 August 2008 / Published: 30 September 2008

\begin{abstract}
We have studied the effect of simultaneous oral treatment of aqueous garlic extract (Allium sativum) on heavy metal (nickel II and chromium VI) induced changes in serum lipid profile. Nickel sulfate and potassium dichromate treated rats showed a significant increase in serum low density lipoprotein-cholesterol (LDL-C), very low density lipoprotein-cholesterol (VLDL-C) and triglyceride (TG) level as well as decrease in serum high density lipoprotein-cholesterol (HDL-C) level. Simultaneous garlic administration with nickel sulfate showed improvement in serum LDL-C, HDL-C, VLDL-C and TG level. But in case of potassium dichromate, garlic administration did not show satisfactory improvement in lipid profile except VLDL-C and TG level. The results indicate that garlic (Allium sativum) has some beneficial effect in preventing heavy metal (nickel and chromium VI) induced alteration of lipid profile.
\end{abstract}

Keywords: Garlic (Allium sativum), nickel sulfate, potassium dichromate, serum lipid profile

\section{Introduction}

There has been a significant application of metals in the various industries due to a general global increase in industrial activity over the past few decades. This in turn causes a great escalation of metal in the environment. Although some metals are essential to human health, these may act as toxicants when humans or animals are exposed to high concentration. In this regard nickel and chromium are considered potential health hazards although in some amount they are essential to human health. Both these metals are major components of stainless steel and their salts are used extensively in electroplating industries. After entering the body, nickel penetrates organs and accumulates primarily in bone, liver and kidney, being excreted in bile and urine [1,2]. Although chromium (III) is an essential nutrient to produce various biochemical processes, chromium (VI) is reported as toxic element. It has been reported that both nickel and chromium (VI) can cause an increase triglyceride and phospholipids in serum associated with liver necrosis [2-5]. A study by Kumar et al demonstrated that there is increased accumulation of lipids in liver of rats after orally exposed to chromium (VI) [6]. Nickel also induces severe liver and kidney damage by altering several marker enzymes and ascorbate-cholesterol metabolism [7]. The most plausible mechanism that may be operative in vivo is the generation of reactive oxygen species (ROS) by nickel and chromium, which initiates lipid peroxidation (LPO), thereby causing oxidative damage to critical macromolecules like proteins, DNA as well as cell damage/ death $[8,9]$. For thousands of years, amazing medicinal power has been attributed to garlic. Garlic is a hardy perennial bulb, native to the Mediterranean regions of Africa and Europe. Garlic is said to lower serum cholesterol, enhance fibrinolytic activity and inhibit platelet aggregation [10-13]. There is also a report on the beneficial effects of garlic extract in controlling hyperlipidemia in animals [14]. All these effects are attributed to the presence of various organosulfur compounds, mainly allicin in garlic [15]. Garlic compounds are having tremendous antioxidant property 
which exerts actions by scavenging ROS, enhancing cellular antioxidant enzymes and increasing glutathione in the cells [16].

As the previous studies showed that raw garlic is more beneficial than its other form $[17,18]$, the presents study was designed to ascertain the effect of fresh raw garlic aqueous homogenate on heavy metal (nickel sulfate and potassium dichromate) induced alteration of serum lipid profile in male albino rats.

\section{Materials and Methods}

Adult (aged 60-70 days) laboratory bred male Wister rats weighing $160 \pm 5 \mathrm{~g}$ each were fed with laboratory stock diet and water ad libitum for 7 days. The acclimatized animals were divided into six groups of six animals each. Group I served as an untreated control. Group II were administered aqueous homogenate of fresh raw garlic at a dose of $250 \mathrm{mg} / \mathrm{Kg}$ b.wt; orally [19]. Group III was treated with nickel sulfate (New India Chemical Enterprises, Kochi, India) in double-distilled water at a dose of $2.0 \mathrm{mg} / 100 \mathrm{~g} \mathrm{~b} . \mathrm{wt}$, intraperitoneally (i.p.) [20]. Group IV rats received both nickel sulfate $(2.0 \mathrm{mg} / 100 \mathrm{~g}$ b.wt, i.p) and garlic $(250 \mathrm{mg} / \mathrm{Kg}$ b.wt; orally) simultaneously. Group $\mathrm{V}$ rats were given potassium dichromate (Qualigens Fine Chemicals, Mumbai, India) in double distilled water at a dose of 0.5 $\mathrm{mg} / 100 \mathrm{~g}$ b.wt, intraperitoneally (i.p.) [21]. Group VI rats were treated simultaneously with potassium dichromate $(0.5 \mathrm{mg} / 100 \mathrm{~g}$ b.wt, i.p.) and garlic $(250 \mathrm{mg} / \mathrm{Kg}$ b.wt; orally). Nickel sulfate and potassium dichromate were given on alternate days until tenth dose whereas garlic was administered orally every day until twentieth dose. The entire experimental protocol was approved by institutional ethical committee and utmost care was taken during the experimental procedure, as well as at the time of sacrifice, according to the Helsinki Declaration of 1964 [22]. The rats were sacrificed at the end of the last dose after an overnight fast. Blood samples were collected in a centrifuge tube and allowed to form serum. Serum total cholesterol, LDL-cholesterol, high-density lipoprotein (HDL) cholesterol, and triglycerides were assayed using an enzymatic estimation kit (ERBA-diagnostics Mannheim, GmbH, Germany) [23].

Mean \pm SD values were calculated for each group. To determine the significance of inter-group differences, we analyzed each parameter separately. A one way analysis of variance (ANOVA) followed by post hoc ' $t$ ' test was done to determine which of the groups differed among themselves. Duncan's Multiple Range Test was applied with the level of significance fixed at $\mathrm{P}<0.05$ [24].

\section{Results}

Table 1 shows that in Group III and Group V, nickel and chromium induced a significant increase in serum total cholesterol (TC), LDL-cholesterol (LDL-C), VLDLcholesterol (VLDL-C) and triglyceride (TG) levels and a significant decrease in the serum HDL-cholesterol (HDL-
C) level in comparison with the control (Group I). Group IV (nickel sulfate + garlic) also showed a significant elevated level of serum TC, LDL-C, VLDL-C, TG and lowered level of serum HDL-C in comparison with Group I, but LDL-C, VLDL-C, TG levels were significantly lower and HDL-C level was significantly higher than those of Group III (nickel sulfate). But Group VI rats (potassium dichromate + garlic) showed a significant decrease only in serum VLDL-C and TG level, when compared to that of Group V (potassium dichromate).

Table 1: Effect of nickel sulfate and potassium dichromate on serum lipid profile in rats

\begin{tabular}{|c|c|c|c|c|}
\hline $\begin{array}{l}\text { Treatment } \\
\text { group }\end{array}$ & $\begin{array}{c}\text { Total } \\
\text { cholesterol } \\
(\mathrm{mg} / \mathrm{dL})\end{array}$ & $\begin{array}{l}L D L-C H D L-C \\
(m g / d L)(m g / d L)\end{array}$ & $\begin{array}{l}V L D L- \\
C \\
(m g / d L)\end{array}$ & $\begin{array}{c}T G \\
(\mathrm{mg} / \mathrm{dL})\end{array}$ \\
\hline Group-I & $\begin{array}{l}68.55 \pm \\
5.747^{\mathrm{a}}\end{array}$ & $\begin{array}{cc}45.50 & 18.54 \\
\pm 3.008^{\mathrm{a}} \pm 1.270^{\mathrm{a}}\end{array}$ & $\begin{array}{c}16.98 \\
\pm 0.419^{\mathrm{a}}\end{array}$ & $\begin{array}{c}85.24 \\
\pm 3.770^{\mathrm{a}}\end{array}$ \\
\hline Group- II & $\begin{array}{l}69.32 \pm \\
2.287^{\mathrm{a}}\end{array}$ & $\begin{array}{cc}45.76 \quad 19.02 \\
\pm 3.568^{\mathrm{a}} \pm 1.568^{\mathrm{a}}\end{array}$ & $\begin{array}{r}16.29 \\
\pm 1.399^{\mathrm{a}}\end{array}$ & $\begin{array}{c}81.32 \\
\pm 5.601^{\mathrm{a}}\end{array}$ \\
\hline Group- III & $\begin{array}{l}83.22+ \\
4.812^{\frac{\mathrm{b}}{\mathrm{b}}}\end{array}$ & $\begin{array}{cc}63.32 & 11.08 \\
\pm 3.977^{\mathrm{b}} \pm 0.990^{\mathrm{b}}\end{array}$ & $\begin{array}{c}26.63 \\
\pm 0.654^{\mathrm{b}}\end{array}$ & $\begin{array}{r}133.18 \\
\pm 6.934^{b}\end{array}$ \\
\hline Group- IV & $\begin{array}{l}84.02+ \\
3.919^{\mathrm{b}}\end{array}$ & $\begin{array}{cc}54.50 & 16.06 \\
\pm 3.301^{\mathrm{c}} \pm 0.584^{\mathrm{c}} & \end{array}$ & $\begin{array}{l}21.78 \\
\pm 0.564^{\mathrm{c}}\end{array}$ & $\begin{array}{c}126.78 \\
\pm 12.873^{\mathrm{c}}\end{array}$ \\
\hline Group- V & $\begin{array}{l}92.53 \pm \\
3.971^{\mathrm{c}}\end{array}$ & $\begin{array}{cc}71.25 & 13.51 \\
\pm 2.984^{\mathrm{d}} & \pm 0.930^{\mathrm{d}}\end{array}$ & $\begin{array}{c}26.86 \\
\pm 0.527^{\mathrm{b}}\end{array}$ & $\begin{array}{r}133.46 \\
\pm 2.606^{\mathrm{b}}\end{array}$ \\
\hline Group-VI & $\begin{array}{l}89.66 \pm \\
1.668^{\mathrm{c}}\end{array}$ & $\begin{array}{r}72.26 \quad 14.41 \\
\pm 5.360^{\mathrm{d}} \pm 0.952^{\mathrm{d}}\end{array}$ & $\begin{array}{c}21.20 \\
\pm 0.849^{\mathrm{c}}\end{array}$ & $\begin{array}{r}126.86 \\
\pm 8.683^{c}\end{array}$ \\
\hline
\end{tabular}

Treatment groups: I- untreated control; II- garlic; IIInickel sulfate $\left(\mathrm{NiSO}_{4}\right)$; IV- nickel sulfate + garlic; Vpotassium dichromate $\left(\mathrm{K}_{2} \mathrm{Cr}_{2} \mathrm{O}_{7}\right)$; VI- potassium dichromate + garlic. LDL-C, low density lipoproteincholesterol; HDL-C, high density lipoprotein-cholesterol; VLDL-C, very low density lipoprotein-cholesterol; TC, total cholesterol; TG, triglyceride; each value is mean \pm $\mathrm{SD}$ of twelve observations in each group

Fig. 1 shows the percent increase of serum TC, LDLC, VLDL-C, TG level and percent decrease in serum HDL-C level in Group IV in comparison with Group I. but when compared with Group III, receiving nickel sulfate only, the rise in LDL-C, VLDL-C, TG and fall in HDL-C were remarkably less (E2 vs. E3). But such type of improvement was not found when E4 and E5 were compared except serum VLDL-C and TG level (E4 vs. E5). Rats receiving garlic homogenate alone (Group II) did not show any significant variation in the parameters studied above when compared to control group. 


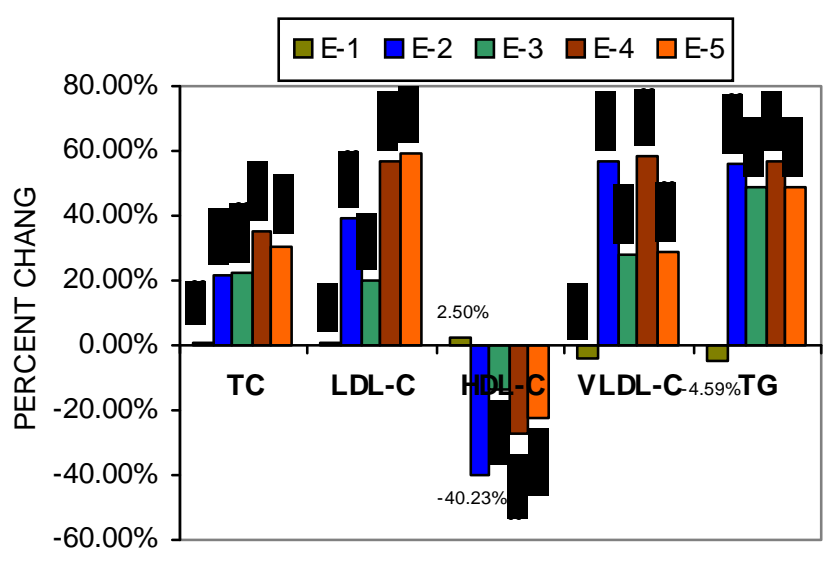

Figure 1: Percent change chart of serum lipid profile after nickel sulfate and potassium dichromate treatment; $\mathrm{E}$ -1 , Group I (control) vs. Group II (+ garlic); E-2, Group I vs. Group III ( $\left.+\mathrm{NiSO}_{4}\right)$; E-3, Group I vs. Group IV $\left(\mathrm{NiSO}_{4}+\right.$ garlic), E-4, Group I vs. Group V $\left(+\mathrm{K}_{2} \mathrm{Cr}_{2} \mathrm{O}_{7}\right)$; E-5, Group I vs. Group VI $\left(+\mathrm{K}_{2} \mathrm{Cr}_{2} \mathrm{O}_{7}+\right.$ garlic $)$

\section{Discussion}

Lipid is an important part of a healthy body because it is used to form cell membranes, several hormones and is necessary for other cellular functions. The various forms of lipids cannot dissolve in the blood and must be transported to and from the cells by low density and high density lipoproteins. High density lipoprotein cholesterol (HDL-C) tends to carry cholesterol away from arteries back to the liver. Therefore, high serum cholesterol level can be due to hepatic dysfunction.

Nickel and chromium induced rise in serum TC, LDL-C, VLDL-C and TG and fall in serum HDL-C in Group III and Group V rats may be due to changes in gene expression of some hepatic enzyme like HMG-CoA reductase (hydroxyl-methyl-glutaryl-CoA), which in turn depresses LDL-receptor gene expression [25, 26]. The rise in serum triglyceride is possibly due to hypoactivity of lipoprotein lipase in blood vessels which breaks up TG. The high TG level along with decreased absorption of fatty acids by adipose tissue is associated with a low level of HDL-C, insulin resistance and increased risk of atherosclerosis [27]. In our study, high cholesterol level in chromium intoxication may also be due to decreased activity of cytochrome P450 enzymes [28]. The rise in serum lipid profile may also be attributed to increased lipolysis, mediated by increased norepinephrine release which act through interference with the intracellular functions of $\mathrm{Ca}^{+2}$ in the cytoplasm [29]. The higher toxicity of chromium VI than its trivalent form may be due to its greater penetrating power into the cell as it exists as tetrahedral chromate anion resembling the forms of other natural anions. Moreover, once taken into the cell, this chromium (VI) undergoes reduction to chromium (III) involving intracellular ascorbate, glutathione [30, 31] along with vitamin $\mathrm{E}$ in all tissues [32]. All these events may lead to increased production of ROS, inducing oxidative stress [33] resulting in metabolic dysfunction in the present study. When compared to Group III, the significant improvement of lipid profiles in Group IV rats treated simultaneously with nickel sulfate and garlic agrees with the previous studies that garlic is a hypolipidemic agent [34] that can help in decreasing the level of LDL-C, VLDL-C, TG and in increasing the level of HDL-C. No change of serum TC level in Group IV and Group VI rats suggests that, raw garlic extract may not have influence on cholesterol biosynthetic pathway. A significant decrease in serum TG level in both Group IV and Group VI rats was supportive to other studies [35] and may be due to the TG-lowering effect of garlic by inhibition of fatty acid synthesis [36]. There is also report that garlic can depress the hepatic activity of lipogenic, cholesterogenic enzymes such as malic enzymes, fatty acid synthase, glucose-6-phosphate dehydrogenase [37]. As these heavy metals exert their toxic effects in the way by producing ROS, raw garlic homogenate may combat this oxidative stress through modulatory effects on ROS $[38,39]$. But surprisingly, in the present study, garlic was found to be less effective to counteract chromium induced alteration of lipid profile.

Hence it can be concluded from the present study that both nickel sulfate and potassium dichromate adversely affect the serum lipid profile. Simultaneous treatment with garlic relatively improved serum lipid profile in nickel treated rats than its chromium treated counterpart.

Acknowledgements: The authors greatly acknowledge the Director, Defence Institute of Physiology and Allied Sciences, New Delhi (DRDO, Ministry of Defence, Government of India) for providing financial assistance (Ref.No. TC/292/TASK-116(KDS)/DIPAS/2006). The authors also acknowledge Dr. B. S. Patil, Dean, Al-Ameen Medical College, Bijapur, Karnataka, India for his constant encouragement during this study.

\section{References}

1. Agency for Toxic Substances and Disease Registry (ATSDR). Toxicological Profile for Nickel. U.S. Department of Health and Human Services, Public Health Service, ATSDR. Atlanta, Georgia, USA: U.S. Government Printing Office, 2003, 5-16.

2. Agency for Toxic Substances and Disease Registry (ATSDR). Toxicological Profile for Chromium. U.S. Department of Health and Human Services, Public Health Service, ATSDR. Atlanta, Georgia, USA: U.S. Government Printing Office, 2000, 122-152.

3. Das, K. K.; Gupta, A. D.; Dhundasi, S. A.; Patil, A.M.; Das, S. N.; Ambekar, J. G.: Effect of Lascorbic acid on nickel induced alteration in serum lipid profiles and liver histopathology in rats. J. Basic. Clin. Physiol. Pharmacol. 2006, 17 (1), 29-44.

4. Glaser, U.; Hochrainer, D.; Klöppel, H.; Kuhnen, H.: Low level chromium (VI) inhalation effects on 
alveolar macrophages and immune functions in Wistar rats. Arch. Toxicol. 1985, 57, 250-256.

5. Kaufman, D. B.; DiNicola, W.; McIntosh, R.: Acute potassium dichromate poisoning: Treated by peritoneal dialysis. Am. J. Dis. Child. 1970, 119, 374376.

6. Kumar, A.; Rana. S. V. S.: Lipid accumulation in chromium-poisoned rats. Int. J. Tissue. React. 1982, 4(4), 291-295.

7. Das, K. K.; Dasgupta, S.: Studies on the role of nickel in the metabolism of ascorbic acid and cholesterol in experimental animals. Ind. J. Physiol. Allied. Sci. 1998, 52, 58-62.

8. Das, K. K.; Das, S. N.; Dasgupta, S.: The influence of ascorbic acid on nickel induced hepatic lipid peroxidation in rats. J. Basic. Clin. Physiol. Pharmacol. 2001, 12, 187-194.

9. Doreswamy, K.; Shrilatha, B.; Rajeshkumar, T.; Muralidhara.: Nickel induced oxidative stress in testis of Mice: Evidence of DNA damage and Genotoxic effects. J. Androl. 2004, 25, 996-1003.

10. Chutani, S. K.; Bordia. A. The effect of fried versus raw garlic on fibrinolytic activity in man. Atherosclerosis. 1981, 38, 417-421

11. Makheja, A. N.; Beiley, J. M. Antiplatelet constituents of garlic and onion. Agents. Action. 1990, 29, 360-363.

12. Ali, M.: Mechanism by which garlic (Allium sativum) inhibits cyclooxygenase activity. Effect of raw versus boiled garlic extract on the synthesis of prostanoids. Prostaglandins. Leukot. Essent. Fatty. Acids. 1995, 53, 397-400.

13. Srivastava, K. C.: Aqueous extraction of onion, garlic and ginger inhibit platelet aggregation and alter arachidonic acid metabolism. Biomed. Biochem. Acta. 1984; 43, 335-336.

14. Ali, M.; Al-Qattan, K. K.; Al-Enezi, F.; Khanafer, R. M.; Mustafa, T. Effect of allicin from garlic powder on serum lipids and blood pressure in rats fed with a high cholesterol diet. Prostaglandins. Leukot. Essent. Fatty. Acids. 2000, 62, 253-259

15. Augusti, K. T.; Mathew, P. T.: Lipid lowering effect of allicin (Diallyl Diasulfide oxide) on long term feeding to normal rats. Experientia. 1974, 30, 468470.

16. Borek, C.: Antioxidant health effects of aged garlic extract. J. Nutr. 2001, 131, 1010-1015.

17. Kleijnen, J.; Knipschild, P.; Ter Riet, G. Garlic, onions and cardiovascular risk factors. A review of the evidence from human experiments with emphasis on commercially available preparations. Br. J. Clin. Pharmacol. 1989, 28, 533-544.

18. Thomson, M.; Al-Qattan, K. K.; Bordia, T.; Ali, M.: Including garlic in the diet may help lower blood glucose, cholesterol and triglycerides. J. Nutr. 2006, 800-802.

19. Banerjee, S. K.; Dinda, A. K.; Manchanda, S. C.; Maulik, S. K.: Chronic garlic administration protects rat heart against oxidative stress induced by ischemic perfusion injury. BMC Pharmacology. 2002, 2, 16.

20. Bordes, E.; Papillion, V. V. Myocardial change induced by nickel and in association with cadmium. Rev. Ig. Bacteriol. Virusal. Parazitol. Epidemol. Pneumotizol. 1983, 32, 51-56

21. Bulikowski, W.; Wozniak, F.; Borzecki, Z.; Radomska, K.; Kaliszuk, K.; Swies, Z.: Effect of potassium dichromate on histopathologic changes in testicles of white rats and results of atomic pilograms on fur. Ann. Univ. Mariae. Curie. Sklodowska. [Med] 1991, 46, 69-73.

22. Declaration of Helsinki (1964), amended by World Medical Assembly, Venice, Italy, 1983. Br. Med. J. 1996, 313(7070), 1448-1449.

23. Bartis, C. A.; Ashwood, E. (eds.): Text Book of Clinical Chemistry, $3^{\text {rd }}$ edition. WB Saunders Co: Philadelphia, Pennsylvania, USA, 1999; pp. 840-841.

24. Steel, R. G. D.; Torrie, J. H.: Principles and Procedures of Statistics, McGraw-Hill: New York, NY, USA, 1960; pp. 99-131.

25. Kantola, T.; Kivisto, K. T.; Neuvonen, P. J.: Grapefruit juice greatly increases serum concentration of lovastatin and lovastatin acid. Clin. Pharmacol. Ther. 1998, 63, 397-402.

26. Kojima, M.; Masui, T.; Nemoto, K.; Degawa, M.: Lead nitrate induced development of hypercholesterolemia in rats; Sterol independent gene regulation of hepatic enzymes responsible for cholesterol homeostasis. Toxicol. Lett. 2004, 154, 3544.

27. Terasawa, Y.; Ladha, Z.; Leonard, S. W.; Morrow, J. D.; Newland, D.; Sanan, D. et al.: Increased atherosclerosis in hyperlipidemic mice deficient in alpha-tocopherol transfer protein and vitamin E. Proc. Natl. Acad. Sci. U S A. 2000, 28, 830-834.

28. Witmer, C.; Faria, E.; Park, H. S.; Sadrieh. N.; Yurkow, E.; O'Connell, S. et al. : In vivo effects of chromium. Environ. Health. Perspect. 1994, 102 (3), 169- 76.

29. Liu, P. S.; Lin, M. K.: Biphasic effects of chromium compounds on catecholamine secretion from bovine adrenal medullary cells. Toxicology. 1997, 117 (1), 45- 53.

30. Blankenship, L. J.; Carlisle, D. L.; Wise, J. P. Sr; Orenstein, J. M.; Dye, L. E.; Patiernoc, S. R.: Induction of apoptotic cell death by perticulate lead chromate: differential effects of vitamin $\mathrm{C}$ and $\mathrm{E}$ on genotoxicity and survival. Toxicol. Appl. Pharmacol. 1997, 146, 270-280.

31. Wiegand, N. J.; Ottenwalder, H.; Bolt, H. M.: The reduction of chromium (VI) to chromium (III) by glutathione: An intracellular redox pathway in the metabolism of the carcinogen chromate. Toxicology. 1984, 33, 341-348

32. Chundawat, R. S.; Sood, P. P.: Vitamins deficiency in developing chick during chromium intoxication and protection thereof. Toxicol., 2005, 21 (1-2), 124-131. 
33. Anad, S. S. Protective effect of vitamin B6 in chromium-induced oxidative stress in liver. J. Appl. Toxicol. 2005, 25 (5), 440-443.

34. Auer, W.; Eiber, A.; Hertkorn, E.; Koehrle, U.; Lorenz, A. et al.: Hypertension and hyperlipidemia: garlic helps in mild cases. Br. J. Clin. Prac. Suppl. 1990, 69, 3-6

35. Mansell, P.; Reckless, J. P. D.: Garlic Effects on serum lipids, blood pressure, coagulation, platelet aggregation and vasodilation. British. Med. J. 1991, 303, 379-380.

36. Nwanjo, H. U.; Oze, G. O. Changes in Serum Lipid Profiles and Heart Rate in Rats Treated With
Aqueous Garlic Extract. Internet. J. Nutr. Wellness. 2007, 4, 1 .

37. Yu-Yan, Yeh Liu, L.: Cholesterol-lowering effect of garlic extracts and organ sulfur compounds: Human and animal studies. J. Nutr. 2001, 131, 9895-9935

38. Banerjee, S. K.; Mukherjee, P.K.; Maulik, S.K. Garlic as an antioxidant: the good, the bad and the ugly. Phytotherap. Res. 2003, 17 (2), 97-106.

39. Ichikawa, M.; Yoshida, J.; Ide, N.; Sasaoka, T.; Yamaguchi, H.; Ono, K. Tetrahydro- $\beta$-carboline derivatives in aged garlic extract show antioxidant properties. J. Nutr. 2006, 136, 726-731. 